\title{
Alternaria blight of oilseed brassicas: A review on management strategies through conventional, non-conventional and biotechnological approaches
}

\author{
Amarendra Kumar*, Rakesh Kumar ${ }^{1}$, Santosh Kumar, Divakar Nandan², Gireesh Chand \\ and S. J. Kolte ${ }^{3}$
}

Department of Plant Pathology, Bihar Agricultural University, Sabour, Bhagalpur-813210 (Bihar), INDIA

${ }^{1}$ Department of Soil Science and Agricultural Chemistry, Bihar Agricultural University, Sabour, Bhagalpur-813210 (Bihar), INDIA

${ }^{2}$ Department of Genetics, University of Delhi South Campus, New Delhi-110021, INDIA

${ }^{3}$ Department of Plant Pathology, Govind Ballabh Pant University of Agriculture \& Technology, antnagar-263145 (Uttarakhand), INDIA

*Corresponding author. E-mail: kumaramar05@gmail.com

Received: September 15, 2015; Revised received: February 11, 2016; Accepted: May 11, 2016

\begin{abstract}
Oilseed Brassicas are contributing approximately 28 percent of the India's total oilseed production. This crop is gaining wide acceptance among the farmers because of adaptability for both irrigated as well as rainfed areas and suitability for sole as well as mixed cropping. Besides, it offers higher return with low cost of production and low water requirement. The production and productivity of oilseed brassicas are comparatively lower as compared to the world average due to the biotic and abiotic constraints. Among the biotic constraints, alternaria blight disease caused by Alternaria spp. has been reported from all the continents of the world, causing up to $70 \%$ yield losses in India. This disease was found on leaves, stems and siliquae and dark spots on the leaves and siliquae reduce the photosynthetic capacity and induce immature ripening, which causes reduced amount of quality seed and oil content. The severity of this disease depends upon weather conditions, varieties, age of host plants and virulence of the pathogens. Efforts are being done throughout the world for the management of alternaria blight of rapeseed-mustard. This paper comprehensively reviews the research of alternaria blight of rapeseed-mustard with special reference to management strategies through conventional, non-conventional and biotechnological approaches that leads to planning the future research. The present scenario demands the traditional and modern biotechnological techniques bringing together for integrated disease management according to the need and availability at farmers level for sustainable management of alternaria blight disease of oilseed brassicas.
\end{abstract}

Keywords: Alternaria blight, Management, Oilseed Brassicas, Pathogens, Symptoms

\section{INTRODUCTION}

Oilseed Brassicas are the third most important oil seed crop in terms of acreage and production after Soyabean and Palm in the world and occupy second position after groundnut in India (Kumar, 2012; Kumar and Chopra, 2014). Among the oilseed crops, India produced $8.03 \mathrm{mt}$ of rapeseed-mustard from $6.36 \mathrm{mha}$ of land with average productivity of $1262 \mathrm{q} / \mathrm{ha}$ during the 2012-13 season (Agricultural statistics at a Glance, 2014). The per capita consumption of edible oils in India has increased from $6.5 \mathrm{Kg}$. during the 1990-91 to 13.8 Kg during 2011-2012 (Economic survey, 201314). Brassicas have been cultivated in India for a very long time. The two species under cultivation are $B$. rapa and $B$. juncea. Among these two B. juncea is cultivated in about six million hectares in the northern states of India, Punjab, Haryana, Rajasthan, Gujarat, Uttar Pradesh, West Bengal and northeastern states during winter season. Three ecotypes of B. campestris ssp oleifera Brown sarson, Yellow sarson and toria are cultivated as catch crop in the northern India. In India, $B$. juncea, commonly known as Indian mustard, is a major cultivated brassica crop in north-west India, followed by limited cultivation of $B$. napus and $B$. rapa for vegetable oil production. To meet the growing demand and make India self-sufficient for edible oils, productivity of the oilseed crops should be increased since the possibility of increasing land under oilseed crops is very limited (Economic survey, 2013-14).

The development of high yielding varieties along with modern production technology leads to increase in production and productivity of rapeseed-mustard but the gap between potential yield and actual yields are widen due to the different biotic and abiotic factors. Amongst the major fungal diseases of oilseed brassicas prevalent in India, Alternaria blight disease is the most important and destructive disease causing heavy losses 
all over the world attacking all Brassica species. Alternaria blight disease caused by Alternaria brassicae (Berk.) Sacc. has been reported from all the continents of the world and is one among the important diseases of Indian mustard causing up to $70 \%$ yield losses with no proven source of resistance against the disease reported till date in any of the hosts (Meena et al., 2010; Meena et al., 2012). This disease appears on leaves and stems of seedlings and adult plants and also in siliquae during the ripening stage. Dark spots on the leaves and siliquae reduce the photosynthetic capacity and induce immature ripening, which causes reduced amount of quality seed production in both vegetable and oleiferous brassicas (Kumar et al., 2014).

The present review deals in brief about the fungal pathogens causing alternaria blight disease, host range, symptoms, epidemiology, disease cycle, Morphological and cultural characteristics, disease management strategies viz. conventional, non-conventional and biotechnological approaches.

Historical perspectives: The historical controversy surrounding the taxonomy of these fungi is because of their high variability in conidial morphology. There are more than 500 taxon of Alternaria in the literature. In addition to that about 400 species names in the old literature on Macrosporium Fries as well as 200 names published in other genera have been considered as basionyms for the names of Alternaria species. Angell (1929) considered Alternaria and Macrosporium synonymous and used the epithet Macrosporium to designate both the genera. Wiltshire (1933) agreed that Alternaria and Macrosporium are congeneric and stated that macrosporium in the original description was used to designate Alternaria type fungi having non-filiform spores and one spore per conidiophores and Alternaria used to designate both the genera. Neergaard (1945) suggested three sections for this genus on the basis of the formation of chains of conidia. The single, short (about 3-5 spores) and long chains (10 or more spores) conidia were known as Noncatenatae, Brevicatenatae and Longicatenatae respectively. He particularly considered the difference between the true beak (eurostrum), as an integral part of the conidium and the false beak (pseudorostrum), that is secondary conidiophores which are essential to generation of conidial chains Simmons laid the foundation of modern concepts for this genus through his research paper entitled "Typification of Alternaria, Stemphylium, and Ulocladium" published in Mycologia in 1967. He examined an authenticated specimen of the type species and redescribed the fungus and named A. alternata (Fries) keissler according to the International rules of Nomenclature. This specimen was assumed to represent Nee's A. tenius Nees (1816) and later compiled by Fries as $A$. tenius Fries (1832) with A. tenius Nees as a synonym. . According to Ellis (1971), genus Alternaria contains 44 species. Alternaria sp. is easily recognized by the morphology of their large conidia. They are catenate, formed in chains or solitary, typically ovoid to ob- clavate, often beaked, pale brown to brown, multicelled and muriform. Simmons (1992) redescribed numerous species and differentiated the genus into numerous species and also developed species-group system within the genus. Fourteen species groups were defined on the basis of conidial characteristics, the pattern of chain formation and the nature of the apical or sometimes lateral extensions of conidial cells.

Geographical distribution: Alternaria blight of rapeseed-mustard, the most common and destructive disease of oilseed brassicas is principally caused by an imperfect fungus, Alternaria brassicae (Berk.) Sacc. Three other species viz. A. brassicicola (Schw.) Wilts., A. raphani Groves and Skolko, A. alternata (Fr.) Keissler, are also associated with the affected plants under natural conditions in India (Kolte et al., 1987).

In temperate climate countries such as Canada, United Kingdom, Poland, Sweden, France, Germany, Holland, Spain, and Cooler parts of India, the disease caused by A. brassicae is much more prevalent than other three species of Alternaria (Chahal and Kang, 1979; Tripathi et al., 1980; Kadian and Saharan, 1983; Kolte, 1985b; Clear, 1992). As a result of survey of forty cruciferous crops, done in the year 1983 in Edinburgh area of United Kingdom, 73 per cent of total crops examined were infected with $A$. brassicae and only 16 per cent of the crops was infected by $A$. brassicicola (Anonymous, 1984). In the Alberta area of Canada, the disease caused by A. alternata is dominant on Polish type of rape and the same is more prevalent on the phylloplane of Brassica campestris and B. napus (Tsuneda et al., 1978; Vaartnou and Tiwari, 1972; Visconti et al., 1992). In contrast to the above, West Bengal state of India Alternaria blight is reported to be predominantly caused by A. brassicicola (Dasgupta et al., 1985; Sarkar and Sengupta, 1978; Satyabrata Maiti, 1989).

Economic importance: Alternaria blight of rapeseedmustard has been found to be a constraint in the production of these crops in countries such as Germany (Stoll, 1948), Sweden (Borg, 1951), England (Loof, 1959), Canada (McDonald, 1959; Degenhardt et al., 1974), and in India (Chahal and Kang, 1979; Kolte, 1982, 1985a, b; Kadian and Saharan, 1983; Kolte et al., 1985, 1987). In India, the rapeseed-mustard crops are regularly affected by Alternaria blight which causes more than 46.57 per cent yield losses in yellow sarson and 35.38 per cent in mustard (Kolte, 1985a). Kolte et al. (1987) and Ram and Chauhan (1998) further reported that Alternaria blight may be responsible for 10-70 per cent average yield losses in rapeseedmustard depending upon prevailing weather and disease situations. Alternaria infections have also been reported to affect the quantitative and qualitative changes in oil content. The loss in oil content of seed from heavily infected rapeseed plants by $A$. brassicae ranged from 14.58 to 39.57 per cent depending upon cultivars whereas in B. juncea it ranged from 14.12 to 29.07 per cent (Ansari et al., 1988).

Host range: Alternaria species are either parasites on 
living plants or saprophytes on organic substrate. The host range of pathogenic Alternaria is very broad. Alternaria affects most cruciferous crops, including broccoli and cauliflower (Brassica oleracea $L$. var. botrytis L.), field mustard and turnip (B. rapa $L$. (synonym: B.campestris L.), leaf or Chinese mustard (B. Juncea), Chinese or celery cabbage ( B. pekinensis), cabbage $(B$. oleracea var. capitata), rape $(B$. campestris) and radish (Raphanus sativus).

Symptoms: All the three species of Alternaria are reported to infect seedling stage on cotyledons and in the adult stage on leaves, petioles, stem, inflorescence, siliquae and seeds. The variation in shape, size, colour and intensity of lesions are found on different host plants under different environmental condition. The initial infection on the lower leaves starts as minute brown to blackish lesions which multiply rapidly and later spread to the upper leaves, stem and siliquae. On the leaves, formation of concentric rings in the lesions and a zone of yellow halo around the lesion is very prominent (Kadian and Saharan, 1983). Several lesions on leaves unite to cause blighting and defoliation under humid weather. With progress, the disease appears on middle and upper leaves with smaller sized spots, when defoliation of lower leaves occurs. The lesions on leaves due to A. brassicicola are sooty black, velvety and copiously covered with black conidiophores and conidia, whereas those caused by $A$. brassicae are gray, dense and sparsely covered with brown conidiophores and conidia (Changsri, 1961). Spots produced by $A$. raphani show distinct yellow halos around them. However, the symptoms may vary with the host and environment. Later, round black conspicuous spots appear on siliquae and stem.The lesions on the stem are at first linear and then expand but remain usually elongated with pointed ends. Deep lesions on the siliquae cause infection in the seed. $A$. brassicae and $A$. brassicicola can affect host species at all stages of growth, including seed. On seedlings, symptoms include dark stem lesions immediately after germination that can result in damping-off, or stunted seedlings. A. raphani produces black stripes or dark brown, sharp-edged lesions on the hypocotyls of the seedling. It grows in the vascular system and rapidly infects the entire seedling (Valkonen and Koponen, 1990). The diseased seeds just beneath the black spot are small, shriveled, gray to brown in colour (Verma and Saharan, 1994). The blight also reduces seed size and impairs seed color and oil content (Kaushik et al., 1984).

Epidemiology: The optimum temperature for growth of A. brassicae and A. brassicicola is $22.5^{\circ} \mathrm{C}$ and 25 $27^{\circ} \mathrm{C}$ respectively. The optimum temperature for conidial germination of $A$. brassicae is at $17-19^{\circ} \mathrm{C}$ and $A$. brassicicola is at $30^{\circ} \mathrm{C}$. Conidia germinate in both light and dark conditions but the maximum growth and sporulation of $A$. brassicae occurs in alternating cycles of light and dark. Dissemination of disease is favoured when the maximum temperature is in the range of 20- $23^{\circ} \mathrm{C}$ and minimum in the range $7-10^{\circ} \mathrm{C}$ with an average relative humidity between 67 and $73 \%$ with frequent rains $(70 \mathrm{~mm})$ and the maximum frequency of rainy days i.e. 6-13 days during rosette to flowering stage of the crop (Awasthi and Kolte, 1989).

Disease cycle: Seeds have no effective role in initiation of the primary infection of $A$. brassicae to mustard crop in the subsequent crop season unless the seeds are stored in cold storage or in a region of low temperature. The primary infection can arise from either diseased stubbles or neighboring volunteer crucifers. The secondary infection takes place through conidia formed on infected leaves or pods and the infection cycle and spore production repeated throughout the growing season under favorable weather condition.

Causal fungi: Alternaria species: $A$. brassicae and $A$. raphani do not sporulate well as compared to A. brassicicola and A. alternata on PDA (Neergaard, 1945; Changsri, 1961; Prasad et al., 1970; Goyal, 1977; Thind, 1977). A. brassicae has brown to brownish gray mycelium dark septate conidiospore with brownish black, obclavate, muriform long beak conidia. Maximum growth of $A$. brassicae has been observed at $20-25^{\circ} \mathrm{C}$ temperature and 5-8 pH. However, the sporulation of $A$. brassicae is reported to be increased on 10 per cent lucern seed decoction agar (McDonald, 1959) and PDA supplemented with mannitol (Thakur, 1985; Thakur and Kolte, 1985).

\section{Alternaria spp. characterization}

Morphological and cultural characterization: Fungi are among the most diverse organism groups on Earth (Hammond, 1995). Broad spectrum disease management strategy depends on understanding of pathogen population structure and mechanisms by which variation arises within populations. The variability of the pathogen is the foundation for development of prebreeding populations which leads to the development of resistant variety. Variation in pathogen populations can generally be detected with standard sets of differential hosts (Flor, 1971). The individual genotypes of a fungal pathogen may differ in many inherited characteristics, for example Morphology, physiology and pathogenecity (Person and Ebba, 1975). Most of the characteristics are governed by genes. New races of fungal pathogens are produced by mutation, recombination of nuclear genes during sexual reproduction and by re-assortment or exchange of genetic material in somatic cells.

The taxonomy of Alternaria is based primarily on the morphology and development of conidia and conidiophores and lesser degree on host plant association and colony morphology (Elliott, 1917; Wiltshire, 1933; Simmons, 1967). Classification of many Alternaria species is particularly difficult due to the variation and plasticity of colony and morphological characteristics. A. brassicae, A. brassicicola A. raphani and A. alternata exhibit some cultural, morphological, pathogenic and genetic variation (Verma and Saharan, 1994; Sharma and Tewari, 1995, 1998). The mycelium and 
conidiophores of the A. brassicae are septate and the colour of mycelium and conidiophores are yellowish brown and chestnut brown to grayish brown respectively. Conidia of $A$. brassicae found single or in chains (upto four) and originated from the small pore of the conidiophore wall, straight or slightly curved, obclavate, $75-350 \mu$ in overall length, $20-30 \mu$ thick in broadest part, the beak about $1 / 3$ to $1 / 2$ the length of conidium and 5-9 $\mu$ thick. 10-11 transverse and 0-6 longitudinal septation are found in conidia. The growth of A. brassicae is slow and less sporulation. Conidia of A. brassicicola are mostly in chains of 20 or more, sometimes branched arising through small pore of conidiophore wall, straight or curved, more or less cylindrical but often slightly swollen at the base, septate, pale to mild olivaceous brown, $18-130 \mu$ long, 8-30 $\mu$ thick in broadest part, the beak usually non-existent or $1 / 6$ the length of conidium and 6-8 $\mu$ thick with less than 6 transverse septa and few upto 6 longitudinal septa. The growth pattern of A. brassicicola is fast, well developed black sooty colony and abundant sporulation. Conidia of $A$. raphani are commonly in chains of 2-3, straight or slightly curved, generally with short beak, dark golden brown or olivaceous brown, $50-130 \mu$ long, $14-30 \mu$ thick in the broadest part with 3-7 transverse and often a number of longitudinal septa. The cottony growth of mycelium and abundant sporulation are found in A. raphani. The colonies of $A$. alternata are usually black or olivaceous black, conidiophores arising solitary or in small groups, simple or branched, pale to mild olivaceous or golden brown. Conidia of A. alternata are branched, ellipsoidal, often with a short conical or cylindrical beak, overall length $20-63 \mu, 9-18 \mu$ thick in broadest part, beak pale, $2-5 \mu$ thick with upto 8 transverse and usually several longitudinal septa. The study on cultural variability in Alternaria species in respect of mycelial growth and sporulation on different temperature, relative humidity, hydrogen ion concentration (Ansari et al., 1989), media (Patni et al., 2005) and light (Ansari et al., 1989) have been done. Variability on the basis of morphology, sporulation, growth and other cultural characteristics also have been reported earlier. Goyal et al. (2011) showed high level of variability in vitro in respect of conidia length, width, beak length and number of septa. Kolte et al. (1989) distinguished three isolates of $A$. brassicae, on the basis of their morphology, sporulation, growth and cultural characteristics, which are prevalent in India. Three distinct A.brassicae isolates, A, C and D are highly virulent, moderately virulent and avirulent respectively (Vishwanath and Kolte, 1997). Pantnagar isolates A, $\mathrm{C}$ and D resembled the Bihar isolate $\mathrm{BH} 1$ and $\mathrm{BH} 2$ and Kanpur isolate K respectively (Kolte et al., 1991). Different temperatures were found optimum for growth and sporulation of $A$. brassicae in a range of $20-25^{\circ} \mathrm{C}$ (Singh et al., 2007) and $20-30^{\circ} \mathrm{C}$ (Meena et al., 2005), respectively. Mycelial growth, sporulation of A. brassicae is also affected by relative humidity and showed variation in its requirement (Meena et al., 2005).

Molecular characterization: The amorphous physical characteristics, toxin production and colony characters of Alternaria spp. have made them difficult to classify satisfactorily (Rotem, 1994). Molecular methods have been used not only in differentiating between species (Kusaba and Tsuge, 1994; Jasalavich et al., 1995; Cooke et al., 1998; Roberts et al., 2000), but also for assessing intra-specific variation (Adachi et al., 1993; Kusaba and Tsuge, 1994; Morris et al., 2000). Hong et al. (1996) studied 53 strains of A. brassicae collected from regions in China for differences in virulence on four differnt groups of Chinese cabbage with varying levels of resistance. Ribosomal DNA sequences, in particular the 5.8s ribosomal DNA (rDNA) and flanking internal transcribed spacer regions ITS1 and ITS2, have been used to study the phylogenetic relationships for one isolate each of Alternaria brassicae, A. brassicicola, A. raphani, A. alternata and Pleospora herbarum.. The 5.8 rDNA sequences from the A. brassicae, A. brassicola, A. raphani and A. alternata were identical but differed at only one base pair from Pleospora herbarum. The internal transcribed spacer sequences, especially ITS1, were very variable in both base composition and length. The 18s rDNA sequences were highly conserved, but enough variability was present to distinguish genera clearly (Jasalavich et al., 1995). Phylogenetic analysis of ITS and mitochondrial small subunit (SSU) rDNA sequences revealed that the Stemphylium spp. were distinct from Alternaria and Ulocladium spp. (Pryor and Gilbertson, 2000). Labuda et al. (2008) clearly separated a new species, A. jesenskae from the other related large-spored and filamentbeaked Alternaria species on the basis of sequences of the ITS1, 5.8S and ITS2 region as well as by its distinctive morphology. RAPD and RFLP markers were used for genetic variation in Alternaria brassicae, $A$. brassicicola, and $A$. raphani collected from geographically diverse regions of the world. UPGMA analysis of RAPD data of isolates of three Alternaria species showed four groups in which intra-regional variation between isolates was less apparent Variation was, however, higher in A. brassicicola, as based on RAPD analysis. Two isolates (from Canada and France) of $A$. raphani also showed variability with different RAPD profiles generated by all five primers tested. Five distinct polymorphic RAPD products were used as hybridization probes for RFLP analysis to detect interand intra-specific variation. Variation among A. brassicae, A. brassicicola, and $A$. raphani was evident. Non-radioactive probes were also used to hybridize with Southern blots of A. brassicae, A. brassicicola, Leptosphaeria maculans, Rhynchosporium secalis and Brassica juncea for the selection of A. brassicaespecific probe(s). Probe AbP3 specifically hybridized with restriction digests of $A$. brassicae but not with those of A. brassicicola or other tested species (Sharma and Tiwari, 1998). Morris et al. (2000) were able to identify a high level of genetic diversity within 
A. alternata populations on tomato using RAPD within and between regions in California. Bock et al. (2002) studied the genetic variation within and between eighteen isolates of Alternaria brassicicola, five isolates of A. alternata, and a single isolate of Rhynchosporium secalis using AFLP. The AFLP analysis distinguished consistently within and between A. brassicicola, A. alternata and Rhynchosporium secalis, however multiple isolates from a particular location tended to cluster together. Despite the absence of an identified sexual stage, A. brassicicola would appear to have a means for generating and maintaining significant variation.

Disease management strategies: There are no single method are available currently which are effective and economical for alternaria blight disease management. Different methods are being integrated including cultural, biological, host resistance and biotechnological approach for the efficient management of alternaria blight diseases of cruciferous plants.

\section{Conventional approach}

Cultural Management: Crop management practices are the oldest and broadly applicable approach to minimize or control the plant diseases. Cultural management may reduce the activity of the pathogen by the use of disease free seeds, crop rotation, green manuring sanitation, rouging, time of planting and use of balanced nutrients.

Sanitation: Sanitation measures may be taken for alternaria blight management by eliminating or reducing the infected seed, debris and weed to prevent the spread the pathogen. Alternaria blight pathogen may survive on weeds and perennial crops viz. Chenopodium album, Convolvulus arvensis, Crambe maritime, Crambe abyssinica and Camelina sativa as chlamydospores/microsclerotia at low temperatures (Tsuneda and Skoropad, 1977) and these host assist this pathogen to propagate and serve as source of inoculums (Chupp and Sherf, 1960; Maude and Humpherson-Jones, 1980) and also in the infected seeds for at least a year at room temperature (Shrestha et al., 2003, Ahmad and Sinha, 2002).

Planting times: The eco-friendly and economical management of alternaria blight may be obtained through knowledge of its timing of incidence in relation to weather factors viz. temperatures, relative humidity (RH) and sunshine hours (Sinha et al., 1992;Awasthi and Kolte, 1994; Dang et al., 1995). The extent of alternaria blight severity on leaves (Meena $e t$ al., 2002) and pods (Sandhu et al., 1985) were higher in late sown crops. A delayed planting results in coincidence of the vulnerable growth stage of plants as with warm (maximum temperature: 18-26oC; minimum temperature: $8-120 \mathrm{C}$ ) and humid (mean $\mathrm{RH}$ $>70 \%$ ) weather condition. Highest frequency of occurrence of $A$. brassicae on leaves and pods was found between 67-84 and 67-142 days after sowing respectively (Chattopadhyay et al., 2005). The minimum disease severity was reported in early sown at $45 \mathrm{~cm}$ row spacing as compared to broadcast method (Kumar and Kumar, 2006).

Biological management: Biological control offers an environmentally friendly approach to the management of plant disease and can be incorporated into cultural and physical controls and limited chemical usage for an effective integrated pest management (IPM) system (Monte, 2001). Trichoderma species have been known as biological agents for control of plant diseases. They produce many components, which induce local or systemic plant resistance to abiotic stress. T. harzianum is a biocontrol agent in control of A. alternata (Roco and Perez, 2001; Monte, 2001; Sempere and Santamarina, 2007). Spray of soil isolates of Trichoderma viride at 45 and 75 days after sowing could manage Alternaria blight of Indian mustard (Brassica juncea) as effectively as mancozeb (Meena et al., 2004). Aspergillus flavus produce fungistatic substance capable of preventing disease development of black leaf spot of mustard cabbage caused by Alternaria brassicicola. The fungistatic substances were inhibiting the germination of A. brassicicola conidia and stable under high temperature and high or low $\mathrm{pH}$ value (Chen et al., 2011). The endophytic fungus Heteroconium chaetospira from roots of Chinese cabbage penetrates through the outer epidermal cells passes into the inner cortex of its host without causing pathogenic symptoms. This fungus suppressed the disease caused by Pseudomonas syringae pv. macricola and Alternaria brassicae on leaves (Hashiba and Narisawa, 2005).

The protective effects observed for certain Bacillus strains make them highly interesting for biocontrol agents in Brassica cultivation. Four Bacillus strains were tested for effects on plant fitness and disease protection of oilseed rape (Brassica napus). The strains belonged to plant-associated Bacillus amyloliquefaciens and a recently proposed species, Bacillus endophyticus. The fungal pathogens tested represented different infection strategies and included Alternaria brassicae, Botrytis cinerea, Leptosphaeria maculans, and Verticillium longisporum. The B. amyloliquefaciens strains showed no or a weak plant growth promoting activity, whereas the $B$. endophyticus strain had negative effects on the plant as revealed by phenological analysis. On the other hand, two of the $B$. amyloliquefaciens strains conferred protection of oilseed rape toward all pathogens tested. In vitro experiments studying the effects of Bacillus exudates on fungal growth showed clear growth inhibition in several but not all cases. The protective effects of Bacillus can therefore, at least in part, be explained by production of antibiotic substances, but other mechanisms must also be involved probably as a result of intricate plant-bacteria interaction (Danielsson et al., 2007). Bacillus subtilis strain UK-9, an isolate from reclaimed soils, was studied for its biological control activity against Alternaria leaf spot disease of mustard. In dual culture, production of antifungal metabolites by the bacteria caused morphological alterations of vegetative cells and spores, disruption and lysis of their cell wall. 
The antagonist reduced spore germination on leaves and disease incidence of the pathogen in plant trial as well as it also demonstrated plant-growth-promoting ability (Sharma and Sharma, 2008). The microbial metabolite fistupyrone isolated from the culture broth of a plant-associated Streptomyces sp. TP-A0569 inhibited infection of the seedlings of Chinese cabbage by Alternaria brassicicola in vivo (Igarashi et al., 2000).

The botanical viz., Neem, Eucalyptus, Datura, Pudina, Tulsi,Lantana were evaluated under crude and boiled forms against $A$. brassicae under in vitro condition (Sasode et al., 2012). The botanical viz., Neem, Eucalyptus, Datura, Pudina, Tulsi,Lantana were evaluated under crude and boiled forms against Alternaria brassicae under in vitro condition Botanicals viz.,bulb extract of Allium sativum has been reported to effectively manage Alternaria blight of Indian mustard (Meena et al., 2004). Patni and Kolte (2006) reported that Eucalyptus globulus, leaf extract showed significant reduction in the radial growth, sporulation and spore germination of A. brassicae. Brinjal (Solanum nigrum) extract component were identified which involved in controlling cabbage black leaf spot disease. An ethanol extract of Solanum nigrum inhibits spore germination of Alternaria brassicicola, the causative agent of cabbage black leaf spot disease. At a concentration of 500 $\mathrm{mg} / \mathrm{L}$, this ethanol extract also cause the germ tubes to become completely swollen. Extract-induced swellings of A. brassicicola germ-tube spores do not cause the symptoms of black spot disease on cabbage leaves. An n-butanol fraction of the ethanol extract exhibit strong antifungal activity; at a concentration of $25 \mathrm{mg} / \mathrm{L}$, a derived sub fraction $(\mathrm{Bu}-11-13)$ show complete inhibition of spore germination (Lin et al.,2011). In the early stages of host-parasite interactions between cauliflower and Alternaria brassicicola lipase interacts closely with epicuticular leaf waxes for adhesion and/ or penetration of the fungal propagules. The lipase produced by ungerminated spores of Alternaria brassicicola plays a crucial role in the infection of cauliflower leaves (Berto et al., 1999).The anti-lipase antibodies containing conidial suspension of $A$. brassicicola reduced the blackspot lesions on intact cauliflower leaves as compared to the surface wax removed cauliflower leaves.

Chemical management: Alternaria blight of rapeseed -mustard can be significantly managed with several fungicides. Kolte and Awasthi (1980) observed that to get effective control of Alternaria blight, the fungicide should be sprayed at appropriate time and at appropriate intervals. Kolte et al. (1989) suggested the iprodione (Rovral) is superior to mancozeb for control of pod infection of Alternaria. Four sprays of Rovaral at 10 days interval reduced the Alternaria blight incidence and increase the seed yield of mustard (Hussain, 1993). Prasad and Lallu (2006) revealed that first spray of carbendazim $(0.1 \%)+$ mancozeb $(0.2 \%)$ followed by two sprays of mancozeb $(0.2 \%)$ at early date of sowing was the best combination in reducing the disease severity on leaves (18.7\%) and pods (10.4\%) higher realization yield $(1295.8 \mathrm{~kg} / \mathrm{ha}), 1000$ seed weight $(5.12 \mathrm{~g})$ and oil content $(42.6 \%)$. Ayub et al. (1996) reported that iprodione (Rovral) reduced disease severity and increased seed yield when applied on 40 days old plants. Mancozeb was the best among all the treatments, resulting in the lowest disease severity on leaves of mustard (Meena et al., 2004). Iprodione (Rovral) spray has been found effective in checking silique infection due to A. brassicae (Cox et al., 1983). Field evaluation of fungicides for the control of Alternaria blight of Indian mustard was done by DasGupta et al. (1985) and found that difolatan (captafol 0.2\%) was highly effective when 4 sprays were given at 10 days intervals. Anwar et al. (2001) reported that Benlate showed best performance and reduced the leaf blight disease incidence of rapeseed-mustard by 76.6\%. Godika et al. (2002) studied the efficacy of some fungicides against Alternaria blight disease of mustard and observed that Antracol sprayed plants showed lowest Alternaria blight severity. Ridomil MZ was most effective to reduce the disease severity of Alternaria blight followed by the combination Carbendazim and Captaf. Topsin-M at a concentration of 500 ppm was the most effective in reducing radial growth of the pathogenic fungi (Khan et al., 2007). Iprovalicarb has an excellent toxicological and ecotoxicological profile. It has excellent fungicidal activity against Plasmopara viticola, Peronospora vicia, Phytophthora $s p$, Alternaria sp in grapes, potatoes, tomatoes, tobacco and vegetables (Maity and Mukherjee, 2009). Signum fungicide containing $6.7 \%$ pyraclostrobine $+26.7 \%$ boscalid has been evaluated in comparison with the fungicides mancozeb, mancozeb + metalaxyl-M and azoxystrobin. It gave comparable or even better results than reference products for disease control against Mycosphaerella spp., Albugo candida and Alternaria spp., Botrytis cinerea and Sclerotinia sclerotiorum in vegetables (Callens et al., 2005).

Alternaria blight resistance source: All cultivated Brassicas are essentially susceptible to A. brassicae and A. brassicicola but there are some differences in their degree of susceptibility (Jasalavich et al., 1993). $B$. napus and B. carinata are less susceptible to $A$. brassicae than $B$. rapa and $B$. juncea (Skoropod and Tewari, 1977; Bhoumik and Munde, 1987; Conn and Tewari, 1989; Katiyar and Chamola, 1994). Hydrophobic surface of epicuticular wax are primarily responsible for the difference of degree of susceptibility (Skoropad and Tewari, 1977; Conn and Tewari, 1989). Some field resistance to $A$. brassicae has been reported in Brassica juncea but under artificial inoculation conditions, most sources failed to withstand pathogen attack (Saharan and Kadian, 1983; Katiyar and Chopra, 1990). Several sources of tolerance against Alternaria blight have been reported (Gupta et al., 2001), including dwarf B. juncea cv. Divya (Kolte et al., 2000). Different components of horizontal resistance were analyzed in Brassica genotypes against A. brassicae 
and found differences in the number of lesions, size of lesions, latent period, sporulation and infection rate (Saharan and Kadian, 1983). Size of lesions and amount of sporulation may be considered as important factors in determining the degree of resistance in Brassica to alternaria blight (Kolte, 1987). Some somaclones of $B$. juncea have high degree of field resistance to A. brassicae but not proved worthwhile in later generations (Katiyar and Chopra, 1990; Sharma and Singh, 1992). Inter specific hybridization between Brassica carinata and $B$. rapa revealed that $F_{1}$ hybrid were free from Alternaria blight but the meiotic studies showed major irregularities, leading to very less pollen stainabilty (Choudhary et al., 2000).

Primitive cultigens of mustard are more susceptible than the recent ones, indicating some degree of response to selection for resistance during cultivation. A great amount of genetic variation exists within the tribe brassicaceae for various traits of agronomic importance including disease resistance (Warwick, 1993). Eruca sativa was found to be highly resistant to a Canadian isolate (Conn and Tewari, 1986; Tewari, 1991b). Sinapsis alba was also found resistant to $A$. brassicae attack (Kolte, 1985a; Brun et al., 1987; Ripley et al., 1992; Sharma and Singh, 1992, Hansen and Earle, 1995, 1997). B. desnottesii, Coincya pseuderucastrum, Diplotaxis berthautii, D. catholica, D. cretacea, D. eruciides and Erucastrum gallicum were found completely resistant in vivo and in vitro against $A$. brassicae (Sharma et al., 2002). The high degree of resistance to $A$. brassicae was found in the wild relatives of Brassica outside the tribe brassicaceae. These are false flux (Camelina sativa), Shepherd's purse (Capsella bursa-pastoris) (Conn et al., 1988) and Neselia paniculata (Tewari and Conn, 1993). Intertribe gene transfer by conventional hybridization is very difficult. Inter-tribe hybrids were obtained with cultivated species but establishment of rooted shoots in soil was either unsuccessful (Narasimhulu et al., 1994; Hansen, 1998) or difficult (Sigareva and Earle, 1999). Under field conditions, inter generic hybridization between Erucastrum canariense and Brassica rapa appeared to be moderately resistant to Alternaria blight and also harboured a significantly lower population of mustard aphid than the cultivated B. rapa (Bhaskar et $a l ., 2002)$. Two inter generic hybrids involving wild species Erucastrum cardaminoides $(2 \mathrm{n}=18, \mathrm{E}(\mathrm{cd}) \mathrm{E}$ (cd)) and two crop brassica species, Brassica rapa (2 $\mathrm{n}=20$, AA) and $B$. nigra $(2 \mathrm{n}=16, \mathrm{BB})$, were synthesized. The E. cardaminoides x B. nigra hybrid and amphiploid appeared to be tolerant to alternaria blight under field conditions (Chandra et al., 2004).

Resistance to A. brassicae in crucifers is layered and multicomponent (Tewari, 1991b; Tewari and Conn, 1993). The structure of wax in Brassica has important role in host resistance and acts as physical barrier without a direct chemical effect. The epicuticular wax forms a hydrophobic coating and reduces the rate of conidium germination and number of germ tubes formed by conidium. High deposition of epicuticular wax in some of the B. napus genotypes were responsible for resistance to $A$. brassicae, which acts as a water repellent resulting reduced conidial retention on the surface of leaves. The leaves of cultivars Midas and Tower have appreciable amounts of epicuticular wax (Skoropod and Tewari, 1977). The epicuticular wax of leaves is organized into two layers i.e. proximal and distal. The proximal layer has plate like crystals, while the distal layer is fluffy, consisting of wax crystals. In resistant genotypes, the distal layer is thicker (Skoropad and Tewari, 1977; Tewari and Skoropad, 1976). The alternaria blight resistant cultivars are characterized by relatively high concentrations of phenols and low concentration of sugars and nitrogen as compared to susceptible cultivars. Higher amount of phenols and lower amount of sugars and nitrogen were found in tolerant genotype RC 781 in comparison to susceptible genotype like Prakash. (Gupta et al., 1984). Yadav et al., (2014) reported that out of 31 genotypes, NPN-1 was found to be resistant with $9.2 \%$ incidence of disease.

The phytoalexins plays significant role in host resistance against alternaria blight in Brassica. Phytoalexins are low molecular weight antimicrobial compounds that are synthesized and accumulated in plants after the interaction between the host and pathogen which results the inhibition of fungal growth on the leaf surface. Some wild crucifers are highly resistant to $A$. brassicae and elicit phytoalexins when challenged by this pathogen (Conn et al., 1988). Phytoalexins elicited in Camelina sativa (L.) crantz consist of camelexin $\left(\mathrm{C}_{11} \mathrm{H}_{8} \mathrm{~N}_{2} \mathrm{~S}\right)$ and 6-methoxycamelexin $\left(\mathrm{C}_{12} \mathrm{H}_{10} \mathrm{~N}_{2} \mathrm{SO}\right)$ (Browne et al., 1991) and these appeared as a first report of naturally occurring thiazoyl-substituted indole phytoalexins which contain a 2- substituted thiazole ring. Thiabendazole, a well known synthetic fungicide, is a 4-substituted thiazole and closely related to camelexin. However, unlike camelexin, thiabenda zole is not toxic to A. brassicae (Maude et al., 1984; Conn et al., 1988). Capsella bursa-pastoris (L.) Medic. elicits camelexin, 6-methoxycamelexin and another phytoalexin, $\mathrm{N}$-methylcamelexin $\left(\mathrm{C}_{12} \mathrm{H}_{10} \mathrm{~N}_{2} \mathrm{~S}\right)$ upon challenge by A. brassicae (Jimenez et al., 1997). A. brassicae has a multitoxin system and produces three phytotoxins i.e. destruxin $\mathrm{B}$, destruxin $\mathrm{B}_{2}$ and homodestuxin B. Destruxin B is the major phytotoxin produced by A. brassicae which causes necrosis and chlorosis on host and non-host plants.

Destruxin B is also produced by Metarhizium anisopliae and some other fungi and it has some insecticidal properties also. The symptoms produced by destruxin B is light dependent and contributed in virulence. The phytotoxin, destruxin B also elicits phytoalexin response in Sinapis alba (Padres and Smith, 1997) and may be involved in resistance to crucifers to A. brassicae. Crucifers transform destruxin B to hydroxydestruxin B. The five cruciferous species Arabidopsis thaliana, Thellungiella salsuginea, Erucastrum 
gallicum, Brassica rapa and Brassica napus are likely to produce a destruxin $\mathrm{B}$ detoxifying enzyme destruxin B hydroxylase similar to other cruciferous species (Pedras et al., 2012)

Non-conventional approach: Brassica plant species has a relatively high nutrient requirement and most soils on which the crop is grown are deficient in one or more nutrients for optimum seed yield and oil and protein content (Grant and Bailey, 1993).

The effect of nutrients on disease resistance may be attributed to (i) effects on plant growth that can influence the microclimate in a crop and thereby affect infection and sporulation of the pathogen, (ii) effects on cell walls and tissues, as well as biochemical composition of the host, (iii) influence the rate of growth of the host, which may enable plants to escape infection in their susceptible stages and (iv) effects on the pathogen through alternations in the soil environments (Colhoun, 1973).

Effect of nitrogen: Nitrogen is the most abundant element in plants, and it has been intensively studied in relation to host nutrition and disease severity. It promotes vigorous growth, delays maturity and is essential for the production of amino acids, proteins, growth hormones, new protoplasm, chlorophyll, phytoalexins and phenols.

The evidence that excessive $\mathrm{N}$ fertilization increases susceptibility to obligate pathogens (Mildews, Club roots) seems to be conclusive, although the form of nitrogen available to the plants may also be significant (Huber and Watson, 1974; Kiraly, 1976). However, high levels of $\mathrm{N}$ usually increase resistance to facultative pathogen in fresh, green, young plant tissue (Kiraly, 1976). These differences in response result from differences in the nutritional requirements of the obligate and facultative type of pathogens. As a rule, all factors which support the metabolic and synthetic activities of host cells and delay senescence of the host plant also increase resistance to facultative pathogens (Marschner, 1986).

Mackenzie (1981) reported that higher doses of nitrogenous fertilizer decreased the disease of Alternaria blight of tomato. Higher dose of nitrogen (140 and 160 $\mathrm{kg} \mathrm{N} / \mathrm{ha}$ ) increased the disease incidence of Alternaria leaf blight of mustard (Khatun et al., 2011). Saharan et al. (1982) observed that the application of $\mathrm{N}$ fertilizer to tomato increased the incidence of Fusarium wilt of tomato plants. Enrichment of foliage with nitrogen may enhance host resistance to Alternaria (Blachinski et al., 1996).

Effect of potassium: Potassium plays a major role in physiological activities of plants and is required in large amounts for adequate crop production. Potassium is a mobile regulator of enzyme activity, is involved in essentially all cellular functions, including photosynthesis, phosphorylation, protein synthesis, translocation, water maintenance, reduction of nitrates and reproduction. A balanced level of $\mathrm{K}$ induces thickened cell walls, accumulation of amino acids and production of new tissues (Mengel and Kirkby, 1978; Perrenoud, 1990; Grant and Bailey, 1993).The mode of action of $\mathrm{K}$ is primarily through plant metabolism and morphology. The K-deficient plants have impaired protein synthesis and accumulate simple $\mathrm{N}$ compounds, like amides, which are good nutrient source for invading pathogens. Tissue hardening and stomatal opening patterns which are regulated by $\mathrm{K}$ are closely related to infection intensity (Huber, 1980; Fageria et al., 1991).

Sharma and Kolte (1994) reported that under natural conditions based on the number and size of spots, percent leaf and pod infection, average disease index on leaf and pods and number of spots on stem, K-fertilized plants reduced 30-45 per cent severity of Alternaria blight over N, P and NP fertilized plants in Toria. Higher dose of K $(90 \mathrm{~kg} / \mathrm{ha})$ decreased the incidence of Alternaria leaf blight (Khatun et al., 2011). Chung and Huang (1993) observed that application of $\mathrm{KCl}$ to soil increased the resistance of Chinese kale plants to black spot disease. Singh (1996) observed that under field conditions application of $\mathrm{KMnO}_{4}$ and $\mathrm{KAl}\left(\mathrm{SO}_{4}\right)$ showed reduction in disease index of Alternaria blight in toria. Srinivas et al. (1997) reported that soil application of $\mathrm{KCl}$ reduced the disease intensity and increased the yield over control against Alternaria blight of sunflower.

Effect of sulphur (S): Sulphur is required in protein synthesis and it is an important constituent in the biologically active compounds like biotin, glutathione, thiamine and coenzyme $\mathrm{A}$ and is also important in energy transfer and protein structure (Bidwell, 1979). Sulphur is involved in synthesis of chlorophyll and is also required in Cruciferae for the synthesis of the volatile oils which accumulate as glucosinolates (Marschner, 1986). Its negligible toxicity to animals and low toxicity to plants have made sulphur attractive as a chemical control agent; it is also a common component of integrated pest management programmes because of its low toxicity to beneficial insects (Emmett, 2003).

Sulphur deficiency of oilseed rape negatively affects disease resistance caused by the reduction of sulphur dependent phytoanticipins (Dubuis et al., 2005). Soil applied sulphur was found to increase resistance against a variety of fungal pathogens on different crops (Klikocka et al., 2005). Vishwanath (1987) observed that application of S (through soil application @ $5 \mathrm{~g}$ / $\mathrm{m}^{2}$ ) showed significant increase of Alternaria blight severity on pods of toria, though it had resulted increase in yield as compared to check. In field trials 50 $\mathrm{kg} \mathrm{S} /$ ha showed 40 per cent more disease severity of Alternaria blight over check (no sulphur). However, increasing the application of sulphur above $50 \mathrm{~kg} / \mathrm{ha}$ showed inhibitory effect over disease development. It is interesting that yield in terms of both quality and quantity were highest $50 \mathrm{~kg} \mathrm{~S} / \mathrm{ha}$ (Sharma, 1992). Singh (1996) reported that out of 15 micronutrients tested in vitro, $\mathrm{CuSO}_{4}$ was found to be fungicidal and the remaining micro-nutrients were found to be fung- 
istatic against $\mathrm{AB}$, white rust, and downy mildew of rapeseed. In vitro growth studies also indicate that sulphur gave maximum fungal growth and sporulation to A. brassicae and A. alternata (Hasija, 1969; Vishwanath, 1987).

Effect of calcium (Ca): Although generally applied as fertilizer to neutralize soil $\mathrm{pH}$, Calcium has critical role in cell division, cell development, carbohydrate movement, neutralization of cell acids, cell wall deposition and formation of pectate salts in the middle lamella (Huber, 1980). Calcium is known to be a factor in disease resistance (Agrios, 2005). The insoluble calcium polypectates are resistant to hydrolysis by pectolytic enzymes produced by the pathogens (Vidhyasekaran, 1988).

Examination of black spot lesions on rapeseed leaves by scanning electron microscopy in conjunction with energy dispersive $\mathrm{x}$-ray microanalysis has revealed sequestration of calcium by $A$. brassicae. Therefore, there are possibilities of control of Alternaria blight of rapeseed by soil or foliar application of calcium compounds (Tewari, 1991a,b; Kumar et al., 2014). Foliar spray of calcium compounds sequester the organic acids at the site of infection, and soil application has the potential of boosting calcium content of the plant (Verma and Saharan, 1994; Kumar et al., 2015). The foliar application of $\mathrm{CaSO}_{4}$ at $0.5 \%$ concentration induced resistance to alternaria blight significantly in comparison to different concentration of $\mathrm{KCl}, \mathrm{K}_{2} \mathrm{SO}_{4}$, $\mathrm{ZnSO}_{4}$, and $\mathrm{Na}_{2} \mathrm{~B}_{4} \mathrm{O}_{7}$ (Kumar et al., 2014; Kumar et al., 2015).

Effect of boron (B): Boron has been used as a fertilizer more than 400 years and it seems possible that its earlier use was associated with disease control (Mengel and Kirkby, 1978). Boron is functional in translocation, cellular differentiation and development, carbohydrate metabolism, pollen germination and the uptake and translocation of $\mathrm{Ca}$.

Brandenburg (1938) pointed that the species of Brassica are more sensitive to boron deficiency and show symptom of infection much earlier and Powen's (1939) recommended boron application to soil around broccoli and cabbage plants and found promising results. In vitro effect of Borax, Boric acid, Sodium bicarbonate and TBZ against fruit rotting fungi of citrus showed that only TBZ was effective in inhibiting the mycelial growth (Javed et al., 1995). Boric acid as foliar spray $(0.53 \%)$ gave 20-64 per cent control of Alternaria blight (Vishwanath, 1987). Sharma (1992) observed positive correlation between the application of Boron in combination of micronutrients and fungicide and reduction in severity of Alternaria blight of toria.

Effect of zinc (Zn): Zinc is a metal component and serves as a functional, structural or regulatory co-factor of a large number of enzymes (Marschner, 1986). The most prominent physiological role of $\mathrm{Zn}$ is the interrelationship with auxin. It is thereby essential for cell elongation and growth, a well as being functional in respiration and enzyme regulation (Huber, 1980). Zinc application often increases host resistance to mildew and leaf spot and has suppressive effects on soil-borne diseases and bacterial and virus diseases (Graham, 1983). With Zn deficiency, a leakage of sugars inhibition of protein synthesis occurs with large increase in free amino acids which in turn favour disease development.

Application of $\mathrm{ZnSO}_{4}$ with NPK in mustard give more biomass and seed yield per plant with an increase in number of branches and siliqua per plant by $28.5 \%$ and $21.8 \%$, respectively as compared to NPK applied alone (Lallu and Shanker, 1995). Kaur (2000) reported that $\mathrm{ZnSO}_{4}$ shows inhibitory effect on mycelial growth of A. brassicae. Zinc did not give any consistent effect on the severity of Alternaria blight of mustard (Vishwanath, 1987; Mian and Akanda, 1989).

Biotechnological approach: Non availability of resistance genes within crossable germplasms of Brassica compel to use the biotechnological strategies to develop genetic resistance against this pathogen. The pathogenesis related (PR) proteins are group of plant proteins that are toxic to invading fungal pathogens, but are present in plant in trace amount. Thus, overexpression of PR proteins leads to increased resistance to pathogenic fungi in several crops. Chitinase, capable of degrading the cell walls of invading phytopathogenic fungi, plays an important role in plant defense response. Chitinase gene tagged with an over expressing promoter $35 \mathrm{~S}$ CaMV inhibited the Alternaria brassicae colony size by $12-56 \%$, lesion number and delay in the onset of disease over the non-trangenic contro (Mondal et al., 2003). Glucanase hydrolyzes a major cell-wall component, glucan, of pathogenic fungi and acts as a plant defense barrier. Class I basic glucanase gene, under the control of CaMV 35S promoter, confirmed stable integration and expression of the glucanase gene in mustard transgenics and arrested hyphal growth of Alternaria brassicae by $15-54 \%$ and showed restricted number, size and spread of lesions (Mondal et al., 2007).

Cysteine-rich antimicrobial peptides isolated from plants have emerged as a potential resource for protection of plants against phytopathogens. The cDNA encoding PmAMP1 isolated from western white pine (Pinus monticola) was successfully incorporated into the genome of $B$. napus, and it's in planta expression conferred greater protection against Alternaria brassicae (Verma et al., 2012).

The fungal secondary metabolites derived from nonribosomal peptide synthetases (NPSs) are phytotoxic virulence factors for niche competition with other micro-organisms in many plant pathosystems. However, many of the functions of NPS genes and their products are unknown. The predicted amino acid sequence of $A$. brassicicola NPS genes AbNPS2 showed high sequence similarity with A. brassicae, AbrePsy1, Cochliobolus heterostrophus, NPS4 and a Stagonospora nodorum NPS (Kim et al., 2007). The hyphal filaments interconnected by bridges through anastomoses 
and formed the fungal mycelium. These bridges facilitate the nutrients, water, and signaling molecules throughout the colony. Anastomosis is required for virulence of the fungal necrotroph Alternaria brassicicola Disruption of the anastomosis gene homolog (Aso1) in A. brassicicola resulted in both the loss of self-anastomosis and pathogenicity on cabbage (Craven et al., 2008).

The expression levels of Mitogen-activated protein (MAP) kinase in Arabidopsis or Brassica could be a possible strategy for engineering defense against Alternaria blight disease. MAP kinases have been shown to be required for virulence in diverse phytopathogenic fungi. The amk1 MAP disruption mutants, a homolog of the Fus3/Kss1 MAP kinases in Saccharomyces cerevisiae, showed null pathogenicity on intact host plants. The mutants expressed extremely low amounts of several hydrolytic enzyme genes that were induced over 10-fold in the wild-type during infection. However, amk1 mutants were able to colonize host plants when they were inoculated on a physically damaged host surface, or when they were inoculated along with nutrient supplements (Cho et al., 2007). The involvement of MAP kinase machinery in the pathogenesis of Alternaria blight was investigated in Arabidopsis thaliana. The MAP2K9/MAPK6 module is influenced during pathogenesis of Alternaria blight in A. thaliana ecotype Columbia (Kannan et al., 2012). The expression of both MAP2K9 and MAPK6 simultaneously increased up to middle stage of disease progression. At late stage of disease progression the expression of MAP2K9 decreased and that of MAPK6 increased. The increased levels of MAP2K9 and MAPK6, seem to be necessary for plant to defend the pathogen up to middle stage of infection. Camalexin, the characteristic phytoalexin of Arabidopsis thaliana, inhibits growth of the fungal necrotroph Alternaria brassicicola. Camalexin has been found to activate both AbHog1 and AbSlt2 MAP kinases. Mutant strains lacking functional MAP kinases showed hypersensitivity to camalexin and brassinin. Enhanced susceptibility to the membrane permeabilization activity of camalexin has been observed for MAP kinase AbHog1 and AbSlt2 deficient mutants (Joubert et al., 2011).

The members of plant WRKY transcription factor families are widely implicated in defense-related genes in response to fungal pathogens and hormone stimuli. A set of 13 BnWRKY genes were identified that are responsive to both fungal pathogens and hormone treatments genes in canola (Yang et al., 2009). The novel defence genes in canola by using a cDNA microarray from Arabidopsis were identified. The abundance of transcripts corresponding to 2375 Arabidopsis expressed sequence tags (selected for defence gene identification) following inoculation of canola plants with the fungal necrotrophic leaf pathogen, Alternaria brassicicola were studied. Homology searches using a canola expressed sequence tag database with approximately 6000 unique clones led to identification of ca- nola defence genes (Schenk et al., 2008).

Of the other non-host-resistant/tolerant plants, Sinapis alba, white mustard, is considered to be the most important apart from Arabidopsis. The suppression of $46 \%$ of the genes in the compatible background indicates the possibility of effective and specific recognition of Alternaria in S. alba. Analysis of the 118 genes up-regulated specifically in infected $S$. alba compared with B. juncea showed that 98 genes have similarity to proteins such as receptor-like protein kinase genes, genes involved with calcium-mediated signalling and salicylic acid-dependent genes as well as other genes of known function in Arabidopsis (Ghose et al., 2008). Cramer and Lawrence (2004) identified Alternaria brassicicola genes expressed in planta during pathogenesis of Arabidopsis thaliana. 47 cDNA clones differentially expressed between Alternaria infected Arabidopsis leaves and spore germination in water was selected for sequencing. Seventy-seven percent (36) of the cDNAs had significant homology to fungal sequences from databases examined, including available fungal genomes, while $13 \%$ (11) had no homology to sequences in the databases. All 36 genes had significant matches with genes of fungal origin, while 11 genes did not have significant hits in the databases examined. Five sequences were expressed on the plant leaf surface but not during spore germination in water. These five cDNAs were predicted to encode a cyanide hydratase, arsenic ATPase, formate dehydrogenase, major Alternaria allergen, and one unknown. In order to identify candidate fungal pathogenicity genes and characterize a compatible host response, a suppression subtractive hybridization (SSH) cDNA library enriched for A. brassicicola and Brassica oleracea genes expressed during the interaction was created, along with a fungal cDNA library representing genes expressed during nitrogen starvation (NS). A total of 3749 and 2352 expressed sequence tags (ESTs) were assembled into 2834 and 1264 uni sequence sets for the suppression subtractive hybridization ( $\mathrm{SSH}$ ) and nitrogen starvation (NS) libraries, respectively. BLASTX analyses of the 2834 uni sequence set using the Gen Bank non-redundant database identified 114 fungal genes. Further BLASTN analyses of the genes with unidentifiable origin using a database consisting of the 1264 fungal unisequence set from the nitrogenstarved library identified 94 additional fungal genes (Cramer et. al., 2006).

\section{Conclusion}

Oilseed brassicas crop is gaining importance globally due to its advantage over other oilseeds viz., higher yield potential, low moisture requirement, higher return at low cost of production, wider adaptability for various farming conditions, etc., But, the area, production and productivity of the crop is declining due to various biotic stresses. Alternaria blight of rapeseed-mustard is the most common and destructive disease of oilseed brassicas and that causes reduction in quantity as well 
as quality of seed and oil contents. Due to unavailability of proven source of resistance in cultivated varieties of oilseed brassicas, other strategies of management could be used. The traditional viz. cultural, chemical, biological, nutritional and modern viz. biotechnological approaches may be employed together according to the needs/demands to develop integrated disease management strategies for sustainable, environment friendly and effective management of alternaria blight disease of oilseed brassicas to narrow down the gap between potential and actual yield.

\section{REFERENCES}

Adachi, Y., Watanabe, H., Tanabe, K., Doke, N., Nishimura S. and Tsuge T. (1993) Nuclear ribosomal DNA as a probe for genetic variability in the Japanese pear pathotype of Alternaria alternata. Appl Environ Microbiol., 59: 3197-3205.

Agricultural statistics at a Glance (2014). Ministry of agriculture, Departement of agriculture and cooperation. Govt. of India. pp.39.

Agrios, G.N. (2005). Plant Pathology, 5th Edn., Elsevier Academic Publishers, California, USA, 922 p.

Ahmad, M.S. and Sinha, K.K. (2002). Mycotoxin contamination of mustard seeds during storage. Indian Phytopath 55(3): 299-302.

Anonymous (1984). Oilseed rape. In: Annual Report of the Edinburgh School of Agriculture, 1983, Edinburgh, U.K., pp. 39-40.

Ansari, N.A., Khan M.W. and Muneet, A. (1988). Effect of Alternaria blight on oil content of rapeseed and mustard. Curr. Sci., 57: 1023-1024.

Angell, H. R. (1929). Purple blotch of onion (Macrosporium Porri Ell.) J. Agric. Res. 38: 467-487.

Ansari, N.A., Khan, M.W. and Muheet, A. (1989). Effect of some factors on growth on sporulation of Alternaria brasicae causing Alternaria blight of rapeseed and mustard. Acta Botanica Indica., 17: 49-53.

Anwar, M.J. and Khan, S.M. (2001). Efficacy of some fungicides for the control of leaf blight on rapeseed and mustard. Pak. J. Phytopath., 13: 167-169.

Awasthi, R.P. and Kolte, S.J. (1989) Epidemiology of Alternaria blight of rapeseed and mustard.IDRC (Canada) Brassica-sub-network Meeting, GBPUA\&T, Pantnagar, January, 1989.

Awasthi, R.P. and Kolte, S. . (1994) Epidemiological factors in relation to development and prediction of alternaria blight of rapeseed and mustard. Indian Phytopathol.47: 395- 399.

Ayub, A., Dey, T.K., Jahan, M., Ahmed, H.D. and Alam, K.B. (1996). Foliar spray of fungicides to control Alternaria blight of mustard. Ann. Bangladesh Agric., 6: 4750.

Berto, P., Comménil, P., Belingheri, L. and Dehorter, B. (1999) Occurrence of a lipase in spores of Alternaria brassicicola with a crucial role in the infection of cauliflower leaves. FEMS Microbiol Lett., 180: 183-189.

Bhaskar, B., Ahuja, I., Janeja, S. and Banga, S. (2002) Intergeneric hybridization between Erucastrum canariense and Brassica rapa. Genetic relatedness between $\mathrm{E}(\mathrm{C})$ and A. genomes. Theor Appl Genet., 105: 754-758.

Bhoumik, T.P. and Munde, P.N. (1987) Identification of resistance in rapeseed and mustard against Alternaria brassicae(berk.) Sacc. and some resistant sources. Beitrage trop. Landwirysch. Veterinarmed. 25: 49-53.

Bidwell, R.G.S. (1979). Plant physiology, $2^{\text {nd }}$ ed. Macmillan Publishing Co. Inc., New York, 726 pp.

Blachinski, D., Shtienberg, D., Dinoor, A., Kafkafi, U., Sujkowski, L.S., Zitter, T.A. and Fry, W.E. (1996). Influence of foliar application of nitrogen and potassium on Alternaria diseases in potato, tomato and cotton. Phytoparasitica, 24: 281-292.

Bock, C.H., Thrall, P. ., Brubaker, C. . and Burdon, J.J. (2002) Detection of genetic variation in Alternaria bras sicicola using AFLP fingerprinting. Mycol Res. 106: 428434.

Borg, A. (1951). Some plant diseases and pests in West Gothland (1950). Vaxtskyddsnotiser, Vaxdskyddsant Stockh, 1: 1-7.

Brandenburg, E. (1938). On the principles of boron application in agricultue. Phytopath., 12: 1-112.

Browne, L.M., Conn, K.L., Ayer, W.A. and Tewari, J.P. (1991). The camalexins: new phytoalexins produced in the leaves of Camelina sativa (Cruciferae). Tetrahedron 47: 3909-3914.

Brun, H., Plessis, J. and Renard, M. (1987). Resistance of some crucifers to Alternaria brassicae (Berk.) Sacc. In Proc $7^{\text {th }}$ rapeseed Conf, Paris, pp 1222-1227.

Callens, D., Sarrazyn, R. and Evens, W. (2005). Signum, a new fungicide for control of leaf diseases in outdoor vegetables. Commun Agric Appl Biol Sci. 70: 199-207.

Chahal, A.S. and Kang, M.S. (1979). Influence of the meteorological factors on the development of Alternaria blight of rape and mustard in the Punjab. Indian Phytopath., 32: 171.

Chandra, A., Gupta, M.L., Ahuja, I., Kaur, G. and Banga, S. S. (2004). Intergeneric hybridization between Erucastrum cardaminoides and two diploid crop Brassica species. Theor Appl Genet. 108: 1620-1626.

Changsri, W. (1961). Studies of Alternaria spp. pathogen on cruciferae. Diss. Abstr. 21: 1698.

Chattopadhyay, C., Agrawal, R., Kumar, A., Bhar, L.M., Meena, P.D., Meena, R.L., Khan, S.A., Chattopadhyay, A.K., Awasthi, R.P., Singh, S.N., Chakravarthy, N.V.K., Kumar, A., Singh, R.B., Bhunia, C.K. (2005). Epidemiology and forecasting of Alternaria blight of oilseed Brassica in India- a case study. Z. Pflanzenkr. Pflanzenschutz. J. Plant Dis. Prot.,112: 351-365.

Chen, Y.T., Lin, M.J., Yang, C.H. and Ko, W.H. (2011). Characterization of a fungistatic substance produced by Aspergillus flavus isolated from soil and its significance in nature. N. Biotechnol. 28: 679-83.

Cho, Y., Cramer, R.A. Jr., Kim, K.H., Davis, J., Mitchell, T.K., Figuli, P., Pryor, B.M., Lemasters, E. and Lawrence C.B. (2007) The Fus3/Kss1 MAP kinase homolog Amk1 regulates the expression of genes encoding hydrolytic enzymes in Alternaria brassicicola. Fungal Genet Biol. 44: 543-53.

Chung, W.C. and Huang, J.W. (1993). Effect of mineral elements on disease severity of black spot of Chinese Kale. Plant Pathol. Bull., 2: 78-87.

Chupp, C. and Sherr, A.F. (1960). Vegetable diseases and their control, pp. 549. New York: The Ronald Press Co.

Choudhary, B.R., Joshi, P. and Ramarao, S. (2000) Interspecific hybridization between Brassica carinata and Brassica rapa. Plant Breed. 119: 417-420.

Clear, R.M. (1992). Frequency and distribution of seed borne fungal pathogens in western Canadian Canola-1989 and 
1990. Can. Plant Dis. Surv. 72(1): 21-27.

Colhoun, J. (1973). Effect of environmental factors on plant disease. Ann. Rev. Phytopath.,11: 343-364.

Conn, K.L. and Tewari, J.P. (1989) Interactions of Alternaria brassicae conidia with leaf epicuticular wax of canola. Mycol Res. 93: 240-242.

Conn, K.L., Tewari, J.P. and Dahiya J.S. (1988). Resistance to Alternaria brassicae and phytoalexinselicitation in rapeseed and other crucifers. Plant Sci. 56: 21-25

Conn, K.L. and Tewari, J.P. (1986) Hypersensitive reaction induced by Alternaria brassicae in Eruca sativa, an oil yielding crucifer. Can J Plant Pathol. 8: 348.

Cooke, D.E., Forster, J.W., Jenkins, P.D., Gareth-Jones, D. and Lewis D.M. (1998). Analysis of intraspecific and interspecific variation in the genus Alternaria by the use of RAPD-PCR. Ann Appl Biol 132: 197-209

Cox, T., Souche, J.L. and Grapel, H. (1983). The control of Sclerotinia, Alternaria and Botrytis on oilseed rape with spray treatments of flowable formulation of iprodione. Abstr. 6th Int. Rapeseed Congr, Paris, France, 17-19 May 1983, pp. 928-933.

Cramer, R.A. and Lawrence, C.B. (2004) Identification of Alternaria brassicicola genes expressed in planta during pathogenesis of Arabidopsis thaliana. Fungal Genet Biol. 41: $115-28$

Cramer, R.A., LA Rota, C.M., Cho, Y., Thon, M., Craven, K.D., Knudson, D.L., Mitchell, T.K. and Lawrence, C.B. (2006). Bioinformatic analysis of expressed sequence tags derived from a compatible Alternaria brassicicolaBrassica oleracea interaction.Mol Plant Pathol.7:113-24.

Craven, K.D., Vélëz, H., Cho, Y., Lawrence, C.B. and Mitchell, T.K. (2008). Anastomosis is required for virulence of the fungal necrotroph Alternaria brassicicola. Eukaryot Cell. Apr; 7: 675-83.

DasGupta, B., Chatterjee, B.N., Chowdhury, S. Ghosh, R.K. and Baral, K. (1985). Fungicidal control of Alternaria blight of mustard. J. Oilseeds Res., 2: 148-151.

Dang, J.K., Kaushik, C.D. and Sangwan, M.S. 1995. Quantitative relationship between Alternaria leaf blight of rapeseed-mustard and weather variables. Indian J. Mycol. Plant Pathol., 25: 184-188.

Danielsson, J., Reva, O., Meijer, J. (2007). Protection of oilseed rape (Brassica napus) toward fungal pathogens by strains of plant-associated Bacillus amyloliquefaciens Microb Ecol. 54: 134-40.

Degenhardt, K.J., Skoropad, W.P. and Kondra, Z.P. (1974). Effect of Alternaria black spot on yield, oil content and protein content of rapeseed. Can. J. Plant Sci., 54: 795799.

Dubuis, P.H., Marazzi, C., Staedler, E., and Mauch, F. (2005) Sulphur deficiency causes a reduction in antimicrobial potential and leads to increased disease susceptibility of oilseed rape. Journal of Phytopathol. 153:27-36.

Economic Survey (2013-14), Ministry of Finance, Government of India, Delhi.

Ellis, M.B. (1971). Dematiaceous hyphomycetes. Commonwealth Mycological Institute, U.K.

Emmett, R.W. (2003). Strategic use of sulphur in integrated pest and disease management (IPM) programs for grapevines. Final report overview. Notes prepared for meetings with the Australian agricultural chemical industry. Department of Primary Industries,Mildura Vic. $10 \mathrm{pp}$

Elliott, J.A. (1917). Taxonomic characters of the genera $\mathrm{Al}$ ternaria and Macrosporium. American Journal of Botany
4: 439-476.

Fageria, N.K., Baligar, V.C. and Jones Charles Allan. (1991). Essential Nutrient and Plant Diseases. In : Growth and Mineral Nutrition of Field Crops. Marcel Dekker, Inc., New York, pp. 457-470.

Flor, H.H. (1971) Current Status of the Gene-For-Gene Concept Annual Review of Phytopathol. 9: 275-296.

Fries, E., (1832) Systema Mycologicum, Vol.I. Officiana Berlingianalund, p.520.

Ghose, K., Dey, S., Barton, H., Loake, G.J. and Basu, D. (2008). Differential profiling of selected defence-related genes induced on challenge with Alternaria brassicicola in resistant white mustard and their comparative expression pattern in susceptible India mustard. Mol Plant Pathol. 9: 763-775.

Godika, S. and Pathak, A.K. (2002). Efficacy of some fungicides against white rust and Alternaria blight disease of mustard. Plant Dis. Res., 17: 138-140.

Goyal, K.N. (1977). Effect of pH, carbon and nitrogen nutrition on the growth and sporulation of Alternaria tenuis (A. alternata). Indian J. Mycol. Pl. Pathol., 7: 155157.

Goyal, P , Chahar, M, , Mathur, A.P., Kumar, A. and Chattopadhyay, C. (2011). Morphological and cultural variation in different oilseed Brassica isolates of Alternaria brassicae from different geographical regions of India Indian Journal of Agricultural Sciences 81: 1052-1058.

Graham, R.D. (1983). Effect of nutrient stress on susceptibility of plants to disease with particular reference to the trace elements. Adv. Bot. Res., 10: 221-276.

Grant, C.A. and Bailey, L.D. (1993). Fertility management in Canola production. Can. J. Pl. Sci., 73:651-670.

Gupta, K., Saharan, G.S., and Singh, D. (2001). Sources of resistance in Indian mustard against white rust and Alternaria blight. Cruciferae Newslett., 23: 59-60.

Gupta, S.K., Kumar, P., Yadava, T.P. and Saharan, G.S. (1984). Changes in phenolic compounds, sugars and total nitrogen in relation to Alternaria leaf blight in Indian mustard. Harayana Agric Univ J Res. 14: 535-537.

Hammond, P.M. (1995). Magnitude and distribution of biodiversity. In: Global Biodiversity Assessment (ed. V. H. Heywood. Cambridge University Press, Cambridge, U.K.:107-191.

Hashiba, T. and Narisawa, K. (2005) The development and endophytic nature of the fungus Heteroconium chaetospira. FEMS Microbiol Lett. 252: 191-196.

Hasija, S.K. (1969). Sulfur requirements of Curvularia pallescens Boed., Alternaria Citri Ell.and A. tenuis Auct. Mycopath. Mycol. Appl., 39: 139-143.

Hansen, L.H. (1998). Intertribal somatic hybridization between rapid cycling Brassica oleracea (L.) and Camelina Sativa (L.) Cranz. Euphytica 104: 173-179.

Hansen, H. and Earle, E.D. (1995). Transfer of resistance to Xanthomonas campestris pv. campestris (L.) by protoplast fusion. Theor Appl Genet. 91: 1293-1300.

Hansen, H. and Earle, E.D. (1997). Somatic hybrids between Brassica oleracea (L.) and Sinapis alba (L.) with resistance to Alternaria brassicae (Berk.) Sacc. Theor Appl Genet. 94: 1078-1085.

Hong, C.X., Fitt, B.D.L. and Welham, S.J. (1996). Effects of wetness period and temperature on development of dark pod spot (Alternaria brassicae) on oilseed rape (Brassica napus). Plant Pathol., 45: 1077-1089.

Huber, D.M. and Watson, R.D. (1974). Nitrogen form and plant disease. Ann. Rev. Phytopath., 12: 139-165. 
Huber, D.M. (1980). The soil of mineral nutrition in defense In : Horsfall, J.G. and Cowling, E.B.(eds.).Plant Pathology - An advanced treatise. Academic Press, New York, pp. 381-406.

Hussain, M.D. (1993). Effect of rovral on the yield and incidence of alternaria blight of mustard Pak. J. Agri: Sci; 30: 185-187.

Igarashi, Y., Ogawa, M., Sato, Y., Saito, N., Yoshida, R., Kunoh, H., Onaka, H. and Furumai, T. (2000). Fistupyrone, a novel inhibitor of the infection of Chinese cabbage by Alternaria brassicicola, from Streptomyces sp. TP-A0569. J Antibiot (Tokyo). 53:1117-22.

Jasalavich, C.A., Morales, V.M., Pelcher, L.E. and SeguinSwartz, G. (1995). Comparision of nuclear ribosomal DNA sequences from Alternaria species pathogenic to crucifers. Mycol Res. 99: 604-614.

Jasalavich, C.A., Seguin-Swartz, G., Vogelgsang, S. and Petrie, G.A. (1993). Host range of Alternaria species pathogenic to crucifers. Can J Plant Pathol. 15:314-315.

Javed, M. A., Nasir, M. A. and Bajwa, M. N. (1995). In vitro effect of certain chemicals on colony growth of different post harvest fruit rotting fungi of citrus. Pakistan J. Phytopath., 7: 215-216.

Jimenez, L.D., Ayer, W.A., Tewari, J.P. (1997). Phytoalexins produced in the leaves of Capsella bursa-pastoris (Shepherd's Purse). Phytoprotection. 78: 99-103.

Joubert, A., Bataille-Simoneau, N., Campion, C., Guillemette, T., Hudhomme, P., Iacomi-Vasilescu, B., Leroy, T., Pochon, S., Poupard, P. and Simoneau, P. (2011). Cell wall integrity and high osmolarity glycerol pathways are required for adaptation of Alternaria brassicicola to cell wall stress caused by brassicaceous indolic phytoalexins. Cell Microbiol. 13: 62-80.

Kadian, A.K. and Saharan, G.S. (1983). Symptomatology host range and assessment of yield losses due to Alternaria brassicae infection in rapeseed and mustard. Indian J. Mycol. Pl. Pathol., 13: 319-323.

Kannan, P., Pandey, D., Gupta, A.K., Punetha, H., Taj, G. and Kumar A. (2012). Expression analysis of MAP2K9 and MAPK6 during pathogenesis of Alternaria blight in Arabidopsis thaliana ecotype Columbia. Mol Biol Rep. 39: 4439-4444.

Katiyar, R.K. and Chamola, R. (1994). A note on incorporation of resistance of resistance to Alternaria leaf spot into Brassica juncea from Brassica carinata. New Botanist 21:239-246.

Katiyar. R.K. and Chopra, V.L. (1990). Somaclonally induced earliness in a Brassica juncea germplasm accession with field resistance to important diseases. Plant Breed. 104: 262-264.

Kaur, A. (2000). Characterization on biotically and abiotically induced response of mustard against Albugo candida, Peronospora parasitica and Alternaria brassicae. Thesis, Ph.D. (Plant Pathology), G.B. Pant Univ. of Agric. \& Tech., Pantnagar, 148 p.

Kaushik, C.D., Saharan, G.S. and Kaushik, J.C. (1984). Magnitude of losses in yield and management of alternaria blight in rapeseed-mustard. Indian Phytopathol. 37: 398

Khan, M.M., Khan, R.U. and Mohiddin, F.A. (2007). Studies on the cost-effective management of Alternaria blight of rapeseed-mustard (Brassica spp.) Phytopathol. Mediterr. 46: 201-206.

Khatun, F., Alam, M.S., Hossain, M.A., Alam, S., Malaker, P.K. (2011). Effect of NPK on the incidence of alternaria leaf blight of Mustard. Bangladesh J. Agric res.,36:407-
413.

Kim, K.H., Cho, Y., LA Rota, M., Cramer, R.A. Jr. and Lawrence, C.B. (2007). Functional analysis of the Alternaria brassicicola non-ribosomal peptide synthetase geneAbNPS2 reveals a role in conidial cell wall construction. Mol Plant Pathol. 8: 23-39.

Kiraly, Z. (1976). Plant disease resistance influenced by biochemical effects of nutrients in fertilizers. Proc. Int. Potash Inst. Colloq. 12 ${ }^{\text {th }}$. pp. 33-46.

Klikocka, H. (2005). Effect of sulphur fertilization on yield and extent of potato tuber infection with Streptomyces scabies and Rhizoctonia solani. Fragm. Agron.,88:38-50.

Kolte, S.J. (1982). Diseases of rai and toria and their control. Indian Farming, 32: 91-93.

Kolte, S.J. (1985a). Diseases of Annual Edible Oilseed Crops (Vol. II), Rapeseed-Mustard and Sesame Diseases. CRC Press, Boca Raton, Florida, 135 p.

Kolte, S.J. (1985b). Disease management strategies for rapeseed-mustard crops in India. Agric. Rev., 6: 81-88.

Kolte, S.J., Awasthi, R.P. and Vishwanath. (1985). Field performance of improved toria (Brassica campestris var. toria) varieties against Alternaria blight, downy mildew and white rust diseases. Indian J. Mycol. Pl. Pathol., 15: 211-213.

Kolte, S.J. (1987). Important diseases of rapeseed and mustard in oilseed crops : Niger and Rapeseed Mustard. Proceedings of the Third Oil Crops Network, held in Addis Ababa, Ethiopia, 6-10 October, 1986, 99-106 pp.

Kolte, S.J., Awasthi, R.P. and Vishwanath (1987). Assessment of yield losses due to Alternaria blight in rapeseed and mustard. Indian Phytopath., 40: 209-211.

Kolte S.J, Awasthi RP and Vishwanath K. (1989). Disease problems in Brassicas and research activities at Pantnagar. IDRC (Canada) Oil Crops: Proceedings of the three meetings held at Pantnagar and Hyderabad, India: 43-48.

Kolte, S.J., Awasthi, R.P. and Vishwanth. (1989). Management of major diseases of rapeseed mustard and groundnut in Uttar Pradesh. Indian Phytopathol. 42: 152.

Kolte, S.J., Bardoloi, D.K. and Awasthi, R.P. (1991). The search for resistance to major diseases of rapeseed mustard in India. Proc $8^{\text {th }}$ Int Rapeseed Congr 9-11 July, Saskatoon, Canada 1: 219-225.

Kolte, S.J. and Awasthi, R.P. (1980). Alternaria blight of rapeseed and mustard Assessment of losses and chemical control. Paper presented at seminar on "Achievements of Seventies and Future Challenges in the Field of Oilseeds and Oils", $35^{\text {th }}$ All India Conve n tion organized by OTAI at Bombay from Feb. 16-17.

Kolte, S.J., Awasthi, R.P. and Vishwanath. (2000). Divya mustard: a useful source to create Alternaria black spot tolerant dwarf varieties of oilseed brassicas. Pl Varieties Seeds, 13: 107-111.

Kumar, A., Kumar, S., Kumar, R., Chand, G. and Kolte, S.J. (2014). Fungicidal effect of some non-conventional chemicals for management of alternaria blight disease of mustard. J. Appl. \& Nat. Sci., 6(2): 913-919.

Kumar, A., Kumar, R., Kumar, S., Chand, G. and Kolte, S.J. (2015). Optimization of eco-friendly chemicals on alternaria blight disease progression and yield components of mustard. The Bioscan, 10(2): 705-711.

Kumar, A., Kumar, S., Kumar, R., Chand, G. and Kolte, S.J. (2015). In vitro and in vivo evaluation of eco-friendly chemicals on alternaria blight disease (Alternaria brassicae) management and yield attributes in Indian mustard (Brassica juncea). J. Appl. \& Nat. Sci.,7(1): 43- 
51.

Kumar, N. and Kumar, A. (2006). Effect of cultural practices on alternaria blight in Brassica juncea and B. napus. Indian J. Agric Sc. 76(6): 389-390.

Kumar, A. (2012). Production barriers and technological options for sustainable production of raeseed-mustard in India. Journal of Oilseed Brassica. 3(2): 67-77.

Kumar, D., Maurya, N., Bharti, Y.K., Kumar, A., Kumar, K., Srivastava, K., Chand, G., Kushwaha, C., Singh, S.K., Mishra, R.K. and Kumar, A.(2014). Alternaria blight of oilseed brassicas: A comprensive review. African J. of Microbio. Res. 8(30): 2816-2829.

Kumar, V. and Chopra, A.K. (2014). Ferti-irrigational response of hybrid cultivar of Indian mustard (Brassica juncea $\mathrm{L}$.) to distillery effluent in two seasons. Analitical. Chem.Letters, 4(3): 190-206.

Kusaba, M. and Tsuge, T. (1994). Nuclear ribosomal DNA variation and pathogenic specialization in Alternaria fungi known to produce host-specific toxins. Appl Environ Microbiol. 60: 3055-3062.

Labuda, R., Jr, P.E., Sert, H. and Sterflinger, K. (2008). Alternaria jesenskae sp. nov., a new species from Slovakia on Fumana procumbens (Cistaceae). Microbiol. Res., 163:208-214.

Lallu and Shankar, H. (1995). Effect of micronutrients on Indian mustard. J. Oilseed Res.,12: 128-129.

Lin, T.C., Fan, M.C., Wang, S.Y., Huang, J.W. (2011) Identification of the Solanum nigrum extract component involved in controlling cabbage black leaf spot disease. $J$ Agric Food Chem. 59: 1667-1672.

Loof, B. (1959). Economically important diseases of cruciferous oil crops and possibilities for control, especially by breeding for resistance. Severing Utsadesforn Tidskr, 69: 237-250.

MacKenzie, D.R. (1981). Association of potato early blight, nitrogen fertilizer rate and potato yield. Plant Dis., 65: 575-577.

Maity, A. and Mukherjee, I., (2009). Assessment of Iprovalicarb, a systemic fungicide in/on cabbage (Brassica oleracea var. capitata). Bull Environ Contam Toxicol. 83: 341-347.

Marschner, H. (1986). Relationship between mineral nutrition and plant diseases and pests. In : Mineral Nutrition of Higher Plants. Academic Press, New York, pp. 369390.

McDonald, W.C. (1959). Grey leaf spot of rape in Manitoba. Can. J. Pl. Sci., 39: 309-316.

Maude, R.B. and Humpherson-Jones, F.M.1980. Studies on the seed-borne phases of dark leaf spot Alternaria brassicicolaand grey leaf spot Alternaria brassicae of brassicas. Annals of Applied Biology 95(3): 311-319.

Maude, R.B., Humpherson-Jones, C.G. and Shuring, C.G. (1984). Treatments to control Phoma and Alternaria infections of Brassica seeds. Plant Pathol. 39: 17-32

Meena, P.D., Chattopadhyay, C., Singh, F., Singh, B. and Gupta, A. 2002. Yield loss in Indian mustard due to white rust and effect of some cultural practices on Alternaria blight and white rust severity. Brassica, 4: 18-24.

Meena, P.D., Meena, R.L. Chattopadhyay, C. and Kumar, A. (2004) Identification of Critical Stage for Disease Development and Biocontrol of Alternaria Blight of Indian Mustard (Brassica juncea). J. Phytopathol. 152: 204 -209 .

Meena, P.D., Chattopadhyay, C., Vijay R. Kumar, Meena R.
L. and Rana, U.S. (2005). Spore behaviour in atmosphere and trends in variability of Alternaria brassicae population in India. (In: Abstracts, Global Conference II on Plant Health - Global Wealth organised by the Indian Soc. Mycol. Pl. Pathol.,MPUAT, Udaipur, 25-29 Nov 2005, pp. 91) J.Mycol. Pl. Pathol. 35: 511.

Meena, P.D., Awasthi, R.P., Chattopadhyay, C., Kolte, S.J. and Kumar, A. (2010). Alternaria blight: a chronic disease in rapeseed-mustard, J. Oilseed Res.1:1-11.

Meena, P.D., Rani, A., Meena, R., Sharma, P., Gupta, R. and Chowdappa, P. (2012). Aggressiveness, diversity and distribution of Alternaria brassicae isolates infecting oilseed Brassica in India. African Journal of Microbiol. Res., 6: 5249-5258.

Mengel, K. and Kirkby, E.A. (1978). Principles of plant nutrition. International Potash Institute, Bern, Switzerland.

Mian, I.H. and Akanda, A.M. (1989). Effect of sowing time, irrigation, soil moisture and nutrient status on Alternaria blight of mustard. Bangladesh J. Pl. Pathol., 5: 77-80.

Mondal, K.K., Chatterjee, S.C., Viswakarma, N., Bhattacharya, R.C. and Grover, A. (2003). Chitinase-mediated inhibitory activity of Brassica transgenic on growth of Alternaria brassicae. Curr Microbiol. 47: 171-173.

Mondal, K.K., Bhattacharya, R.C., Koundal, K.R., Chatterjee, S.C. (2007). Transgenic Indian mustard (Brassica juncea) expressing tomato glucanase leads to arrested growth of Alternaria brassicae. Plant Cell Rep. 26: 247252.

Monte, E., (2001). Understanding Trichoderma: Between biotechnology and microbial ecology. Int. Microbiol., 4:1-4.

Morris, P.F., Connoly, M.S. and St. Clair, D.A. (2000). Genetic diversity of Alternaria alternata isolated from tomato in California assessed using RAPDs. Mycol Res. 104:286-292.

Narasimhulu, S.B., Kirti, P.B., Bhat, S.R., Prakash, S. and Chopra, V.L. (1994). Intergeneric protoplast fusion between Brassica carinata and Camelina sativa. Plant Cell Rep 13: 657-660.

Neergaard, P. (1945). Danish species of Alternaria and Stemphylium. Oxford University Press, London, $560 \mathrm{p}$.

Pedras, M.S. and Khallaf, I. (2012). Molecular interactions of the phytotoxins destruxin B and sirodesmin PL with crucifers and cereals: Metabolism and elicitation of plant defenses. Phytochemistry. 77: 129-139.

Padres M.S. and Smith, K.C. (1997). Sinalexin, a phytoalexin from white mustard elicited by destruxin B and A. brassicae. Phytochemistry. 46: 833-837.

Patni, C.S., Kolte, S.J. and Awasthi, R.P. (2005). Inhibitory effect of some plant extracts against Alternaria brassicae causing Alternaria blight of mustard. Journal of Research 4: 71-79.

Patni ,C.S. and Kolte, S.J. (2006). Effect of some botanicals in management of Alternaria blight of rapeseed-mustard. Ann. Pl. Protec. Sci. 14(1): 151-156.

Perrenoud, S. (1990). Potassium and plant health. In : International Potash Institute (Revised ed.) Research Topic No. 3. International Potash Institute, Bern, Switzerland, pp. 1-165.

Person, C. and Ebba, T. (1975). Genetics of fungal pathogens. Genet. Supp. 79: 397-408.

Prasad, R., Khandewal, G.L. and Jain, J.P. (1970). Morphology, physiology and control of Alternaria brassicae on 
Taramera. Indian Phytopath., 23: 105-110.

Prasad, R. and Lallu (2006). Management of Alternaria blight of mustard with combination of chemicals and botanicals. Ann. Pl. Protec. Sci. 14 (2): 400-403.

Pryor, B.M. and Gilbertson, R.L. (2000). Molecular phylogenetic relationships amongst Alternaria species and related fungi based upon analysis of nuclear ITS and mt SSU rDNA sequences. Mycol Res. 104: 1312-1321.

Powen's W.L. (1939). Boron as a fertilizer for western Oregon soils. Science, 40 : 36-37.

Ram, R.S. and Chauhan, V.B. (1998). Assessment of yield losses due to Alternaria leaf spot in various cultivars of mustard and rapeseed. J. Mycopathol. Res., 36: 109-111.

Ripley, V., Thorpe, M., Iler, S., Mizier, K. and Beversdorf, W.D. (1992). Isozyme analysis as a tool for introgression of Sinapis alba germplasm into Brassica napus. Theor Appl Genet. 84: 403-410.

Roberts, R.G., Reymond, S.T. and Andersen, B. (2000). RAPD fragment pattern analysis and morphological segregation of small-spored Alternaria species and species groups. Mycol Res. 104: 151-160.

Roco, A. and Pérez, L. (2001). In vitro biocontrol activity of Trichoderma harzianum on A. alternata in the presence of growth regulators. Plant Biotechnol., 4: 68-73.

Rotem, J. (1994). The Genus Alternaria: biology, epidemiology and pathogenicity. American Phytopathological Society Press, St Paul,MN.

Saharan, A.R., Barna, B. and Kiraly, Z. (1982). Effect of nitrogen nutrition on Fusarium wilt of tomato plants. Ann. Appl. Biol.,10: 245-250.

Saharan, G.S. and Kadian, A.K. (1983). Analysis of components of horizontal resistance in rapeseed and mustard cultivars against Alternaria brassicae. Indian Phytopathol. 36: 503-507.

Sandhu, K.S., Singh, H. and Kumar, R. (1985). Effect of different nitrogen levels and dates of planting on Alternaria blight and downy mildew diseases of radish seed crop. J. Res. Punjab Agril Univ., 22: 285-290.

Sarkar, B. and Sengupta, P.K. (1978). Studies on some aspects of the epidemiology of Alternaria leaf blight of mustard (Brassica spp.). Beit-rage Zur Tropischen Land Wirtshafjt und Veterinaramedizin, 46: 91-96.

Sasode, R.S., Prakash, S., Gupta, A. Pandya, R.K. and Yadav, A.(2012). In vitro study of some plant extracts against Alternaria brassicae and Alternaria brassicicola. Journal of Phytology 2012, 4(1): 44-46.

Satyabrata, Maiti. 1989. Problems of annual edible oilseed crops in India. In view of tropical plant pathology volume V edited by Ray Chaudhary, S.P.; Verma, J.P., New Delhi, India 1-46. Directorate of Oilseed Research, Rajendranagar, Hyderabad, India.

Schenk, P.M., Thomas-Hall, S.R., Nguyen, A.V., Manners, J.M., Kazan, K. and Spangenberg, G. (2008). Identification of plant defence genes in canola using Arabidopsis cDNA microarrays. Plant Biol (Stuttg).10(5): 539-547.

Sempere, F. and Santamarina, M. (2007). In vitro biocontrol analysis of Alternaria alternata(Fr.)

Keissler under different environmental conditions, Mycopathologia, 163(3): 183-190.

Sigareva M.A. and Earle, E.D. (1999). Camalexin induction in intertribal somatic hybrids between Camelina Sativa and rapid cycling Brassica oleracea. Theor Appl Genet. 98: 164-170.

Simmons, E.G. (1967). Typification of Alternaria, Stemphylium, and Ulocladium. Mycologia. 59: 67-92.
Simmons, E.G. (1992). Alternaria taxonomy: current status, viewpoint, challenge. In: Chelkowski, J. and Visconti A., eds. Alternaria: biology, plant disease and metabolites. Amsterdam: Elsevier, pp. 1-35.

Sinha, R.K.P., Rai,B. and Sinha, B.B.P. (1992). Epidemiology of leaf spot of rapeseed mustard caused by Alternaria brassicae. J. Appl. Biol., 2: 70-75.

Singh, M.P. (1996). Induced host resistance against Alternaria blight, white rust and downy mildew of rapeseed : Role of micronutrients, growth regulators and organic acids. Thesis, Ph.D. (Plant Pathology), G.B. Pant Univ. of Agric. \& Tech., Pantnagar, 262 p.

Singh, D., Singh, R., Singh, H., Yadav, R.C., Yadav, N., Barbetti, M., Salisbury, P., Nimbal, S.,Chattopadhyay, C. and Kumar, A. (2007). Cultural and morphological variability in Alternaria brassicae isolates of Indian mustard (Brassica juncea L. Czern \& Coss.). (in) Proceeding of the 12th International Rapeseed Congress, 26-30 March, Wuhan, China 4: 158-60.

Sharma T.R. and Tewari, J.P. (1995). Detection of genetic variation in Alternaria brassicae by RAPD fingerprints. J Plant Biochem Biotech 4: 105-107.

Sharma, T.R. and Tewari, J.P. (1998). RAPD analysis of three Alternaria species pathogenic to crucifers. Mycol Re.s 102: 807-814.

Sharma, S.R. and Kolte, S.J. (1994). Effect of soil-applied NPK fertilizers on severity of black s p o $t \quad d$ i s e a s e (Alternaria brassicae) and yield of oilseed rape. Plant and Soil, 167: 313-320.

Sharma, S.R. (1992). Effect of host nutrition in management of Alternaria blight of Toria. Thesis, Ph.D. (Plant Pathology), G.B. Pant Univ. of Agric. \& Tech., Pantnagar, 235 p.

Sharma, N. and Sharma, S. (2008). Control of foliar diseases of mustard by Bacillus from reclaimed soil. Microbiol Res.163(4): 408-13.

Sharma, T.R. and Singh, B.M. (1992). Transfer of resistance to Alternaria brassicae in Brassica juncea through interspecific hybridization among Brassica. $J$ Genet Breed. 46: 373-378.

Sharma, G., Kumar, V.D., Haque, A., Bhat, S.R., Prakash, S. and Chopra, V.L. (2002). Brassica coenospecies: a rich reservoir for genetic Resistance to leaf spot caused by Alternaria brassicae. Euphytica 125: 411-417.

Shrestha, S.K., Munk, L. and Mathur, S.B. (2003). Survival of Alternaria brassicae in seeds and crop debris of rapeseed and mustard in Nepal. Seed Science and Technol. Journal 31: 103-109.

Skoropod, W.P. and Tewari, J.P. (1977). Field evaluation of the role of epicuticular wax in rapeseed and mustard in resistance to Alternaria blackspot. Can J Plant Sci 57: 1001-1003.

Srinivas, T. Rao, K.C. and Chattopadhyay, C. (1997). Effect of botanicals and chemicals on the management of blight (Alternaria alternata, Alternaria helianthi) of sunflower (Helianthus annus). Zeitschrift-fur-PflanzenkrankheitenUnd-Pflanzenschutz, 104:527.

Stoll, K. (1948). On the Alternaria blackening of Brassicae. Nachr. Bl. Dtsch. Pfisch. Dienst, Berl., N.F., 2 : 174-178.

Tewari, J.P. (1991a). Current understanding of resistance to Alternaria brassicae in crucifers. Proc. GCIRC, $8^{\text {th }}$ Intl. Rapeseed Congr., July 9-11, Saskatoon, Canada, Proc. Vol. 2 : 471-476, P : 84 (Abstr.).

Tewari, J.P. (1991b). Structural and biochemical bases of 
black spot disease of crucifers. Adv. Struct. Biol., 1: 325349.

Tewari, J.P. and Conn, K.L. (1993). Reactions of some wild crucifers to Alternaria brassicae. Bulletin-OILS-SROP 16: 53-58.

Tewari, J.P. and Skoropad, W.P. (1976). Relationship between epicuticular wax and black spot caused by $A$. brassicae in three lines of rapeseed. Can J Plant Sci 68: 297-300.

Thakur, R. (1985). Studies on growth and sporulation of Alternaria brassicae (Berk.) Sacc. Thesis, M.Sc. Ag. (Plant Pathology), G.B. Pant Univ. of Agric. \& Tech., Pantnagar, $92 \mathrm{p}$.

Thakur, R. and Kolte, S.J. (1985). Radish root extract agar, a suitable medium for the growth and sporulation of $\mathrm{Al}$ ternaria brassicae. Cruciferae Newsl., 10: 117-118.

Thind, T.S. (1977). Studies on nutritional requirements of Alternaria alternata. Indian J. Mycol. Pl. Pathol., 7: 197 $-199$.

Tripathi, N.N., Kaushik, C.D. Yadava, T.P. and Yadava, A. K. (1980). Alternaria leaf spot resistant in raya. Har. Agril. Univ. J. Res., 10 : 166-168.

Tsuneda, A. and Skoropad, W. P. (1977). Formation of microsclerotia and chlamydospores from conidia ofAlternaria brassicae. Can. J. of Botany, 55(10): 12761281

Tsuneda, A., Skoropad, W.P. and Tewari, J.P. (1978). Phylloplane fungal flora of rapeseed. Trans. Br. Mycol. Soc., 70: 329-334.

Vaartnou, H. and Tiwari, I. (1972). Alternaria alternata, parasitic on rape in Alberta. Plant Dis. Reptr., 56: 676677.

Verma, R.P. and Saharan, G.S. (1994). Monograph on Alternaria diseases of crucifers. Saskatoon Research Station, Technical Bulletin, $162 \mathrm{p}$.

Verma, S.S., Yajima W.R., Rahman, M.H., Shah, S., Liu, J.J., Ekramoddoullah, A.K. and Kav, N.N. (2012). A cysteine-rich antimicrobial peptide from Pinus monticola (PmAMP1)confers resistance to multiple fungal patho- gens in canola (Brassica napus). Plant Mol Biol.79(12): 61-74.

Vidhyasekaran, P. (1988). Physiology of Disease Resistance in Plants. Vol. II. Boca Raton, Florida, CRC Press Inc., $128 \mathrm{p}$.

Visconti, A., Sibilia, A. and Sabia, C. (1992). Alternaria alternata from oilseed rape: Mycotoxin production and toxicity to Arlemia salina larvae and rape seedlings. Mycotoxin Res., 8: 9-16.

Vishwanath (1987). Studies on some fungicides and micronutrients in the control of three important disease of Toria (Brassica campestris var. toria). Thesis, M.Sc. Ag. (Plant Pathology), G.B. Pant Univ. of Agric. \& Tech., Pantnagar, 235.

Vishwanath, K. and Kolte, S.J. (1997). Variability in Alternaria brassicae: Response to host genotypes, toxin production and fungicides. Indian Phytopath. 50(3): 373381.

Valkonen, J.P.T. and Koponen, H. (1990). The seed-borne Alternaria raphani and A. brassicicola. Can. J. Microbiol. 33: 850-856.

Warwick, S.I. (1993). Wild species in the tribe Brassicaceae (Cruciferae) as sources of agronomic traits. Part IV In: Guide to the wild Germplasm of Brassica and Allied crops. Technical Bull. 1993-17E, Center Land and Biological Resources Research, Research Branch, Agriculture Canada, pp 1-19.

Wiltshire, S.P. (1933). The foundation species of Alternaria and Macrosporium. Trans. British Mycol. Society 28: 135 -160 .

Yadav, R.B., Kumar, A., Kumar, A. and Verma, S.K. (2014). Screening of rapeseed-mustard cultivars/lines for resistance against alternaria blight. Indian J. Sci. Res. 5 (1): 89-91.

Yang, B., Jiang, Y., Rahman, M.H., Deyholos, M.K. and Kav, N.N. (2009) Identification and expression analysis of WRKY transcription factor genes in canola (Brassica napus L.) in response to fungal pathogens and hormone treatments. BMC Plant Biol. 3: 9:68. 